\title{
Assessment on earthquake resistance spectral design load criteria for buildings and infrastructures in Indonesia
}

\author{
I Wayan Sengara ${ }^{1,2 *}$ and Fahmi Aldiamar $^{3}$ \\ ${ }^{1}$ Professor, Civil and Environmental Engineering Faculty, Institut Teknologi Bandung, Bandung, Indonesia \\ ${ }^{2}$ President, Indonesian Earthquake Engineers Association \\ ${ }^{3}$ Geotechnical Division, Institute of Road and Bridge Research and Development, Ministry of Public Works, \\ Bandung, Indonesia
}

\begin{abstract}
General assessment on earthquake resistance spectral design load criteria for buildings and infrastructures associated with the recent development of Indonesian seismic hazard maps is presented in this paper. The assessment is directed toward general identification of their associated risks for input to policy formulation of disaster risk reduction management plans or strategies. Indonesian seismic hazard maps haveevolved for the last three decades. This is originated from an early development map before 2002, where a seismic hazard map particularly for buildings (1983) was developed adopting the early process of probabilisticseismic hazard analysis (PSHA) for 200 years return period (RP). Further, a 2002 version seismic hazard maphas been developed in the form of peak ground acceleration (PGA) for 500 years RP. Spectral design criteriafor buildings and bridges have been later developed by updating PSHA involving new seismic source zones, ground-motion predictive equations, and various earthquake RP, accommodating seismic codes for buildings( 2500 years RP), for bridges (1000 years RP) and dams involving various RP up to 10,000 years RP correspond to its design level. The spectral accelerations also have included PGA, short $(0.2 \mathrm{~s})$ period, and 1-s period. The latest update hazard maps (2017) have been developed and adopted for seismic codes for buildings, bridges, dams, and other related infrastructures. The increase in spectral design load criteria is identified to assess the general risk of existing constructions, considering the results of several recent building damage surveys. Adoption of new seismic codes based on the most recent hazard maps along with its enforcement is expected to contribute to seismic disaster risk reduction in Indonesia.
\end{abstract}

\section{Introduction}

Since Indonesia is located within the four tectonic plates, i.e., Eurasian, Indian-Australian, Pacific, and Philippine plates, many areas in Indonesia are highly potential for seismic hazards. The most recent major earthquakes that hit Indonesia in the last two decades havecaused significant fatalities, major damages, and losses. It has been highlighted by many researchers, associations, and institutions that earthquake resistance design and construction of buildings, dams, bridges, and other infrastructures in Indonesia needs to become a priority and it is a crucial factor for earthquake disaster risk reduction.

It infers the demands to enhance the building codes and guidelines continuously, considering that structural design under earthquake shall be the vital factor of the future building performance. One of the significant efforts must be pointed to the development of the seismichazard map to be adopted in building and infrastructurecodes adopting quality improvement of new seismic source data and using the most current seismic hazard analysis methodology. The codes shall later be legally referred to and embedded within the local regulations.

Damage occurring during earthquakes needs to be identified and extensively studied, and further research needs to be conducted, ultimately leading to the development of improved building codes. Evidence from past earthquakes indicates adoption and enforcement of the latest model building codes is one ofthe most effective seismic mitigation strategies availableto communities.

Many disciplines are involved in earthquake disaster risk reduction. All groups shall work as collaborative efforts to provide the level of protection needed by communities. The activities are illustrated by followingthe ten-circle of disaster risk-chain management, as shown in Fig. 1. The chain consists of several activitycomponents from research in earthquake hazards and earthquake engineering, seismic hazard mapping, seismic building codes formulation, dissemination of the building codes, building design, building codes compliance/enforcement,

* Corresponding author: wayansenggara@si.itb.ac.id 
construction supervision for the quality assurance and quality control, research on building vulnerability, risk assessment process, disaster risk-reduction management planning, and back to research in hazards and earthquake engineering. The implementation of its risk reduction activities should beintegrated and linked with the efforts of preventing or minimizing the potential break of any chain.

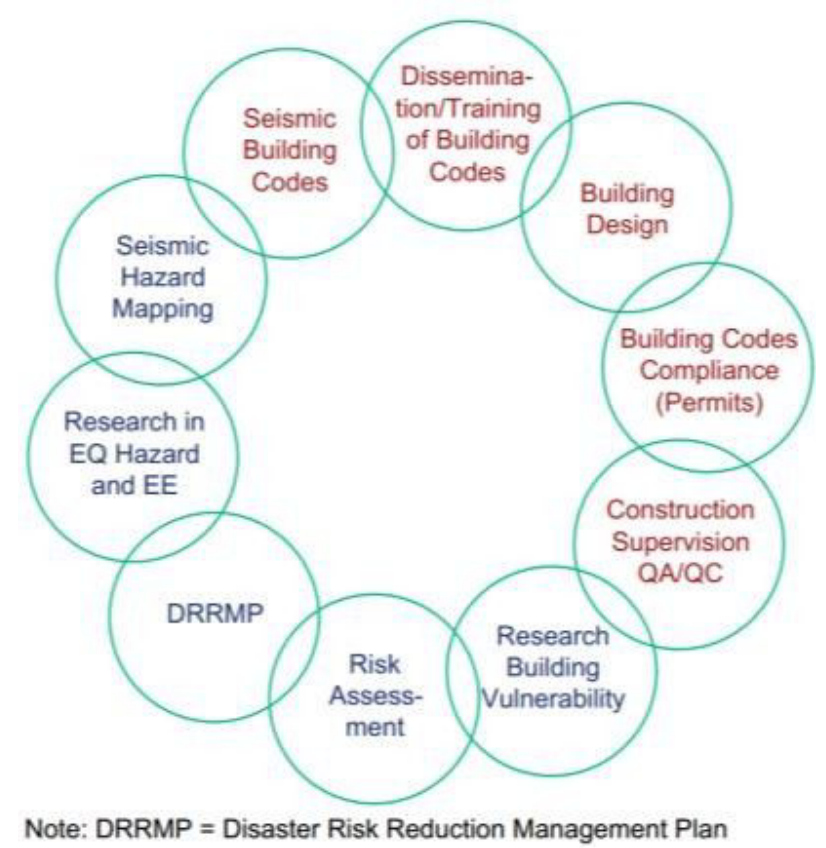

Fig. 1. Ten-Circle of Disaster Risk Chain Management for Seismic Mitigation Strategies.

This paper presents a general assessment of earthquake resistance spectral design load criteria for buildings and Infrastructures in Indonesia. In particular, the paper presents the enhancement of new seismic hazard maps adopted in new codes through the developmentof the most recent development of international building codes, to be adopted for new constructions. General identification is also made on previous hazard maps adopted for existing buildings and several infrastructures (bridge and dam). Some post-disaster building and bridge surveys are also presented in this paper, with information on the development of building vulnerability models, and the need for the development of infrastructure vulnerability models as an input in the seismic risk-reduction process for formulation of risk-reduction management plans. A particular emphasis is made on the compliance of codes as one of the main risk-reduction efforts for both central and local government officials.

\section{Development of Indonesian Seismic Hazard and Mapping}

In general, an earthquake is a natural phenomenon that comprises uncertainty, and consequently, it is very complex in nature to predict when and where an earthquake will occur and with what strength. The effectof an earthquake at the location of a structure is in the form of the ground-motion acceleration that will exert inertial load on the structures. The earthquake and its load are random variables as a natural phenomenon. Therefore, seismic hazard analysis and its mapping are predicted through either or both deterministic and probabilistic analysis, involving seismic sources and their seismic parameters in combination with ground-motion predictive equations.

First Indonesian hazard maps had been developed asa result of a study by Beca Carter in bilateral cooperation between Indonesia and New Zealand (Beca Carter Hollings and Ferner, 1978). This earthquake map divides Indonesia into six earthquake zones. The map was developed adopting a probabilistic approach with an earthquake return period of 200 years. Later on in the year 2002, there was an update of the Indonesian seismic hazard map particularly developed for building codes of 2002. This map is a compilation of four earthquake maps resulting from PSHA of four different research teams from Institut Teknologi Bandung (Firmansyah and Irsyam, 1999), Ministry of Public Works (Najoan etal., 1999), Geological Research Center (Kertapati, 1999), and Consultants (Shah and Boen, 1996). The hazard map was developed for reference baserock $\left(\mathrm{S}_{\mathrm{B}}\right)$ adopting a $10 \%$ probability of exceedance (PE) in 50years (equivalent to an earthquake return period of 475 years).

After the 2002 Indonesian seismic building codes [12], many studies have been conducted toward the improvement of Indonesian seismic hazardmaps. The improvement was directed towards the adoption of the most recent data and current state of knowledge in probabilistic and deterministic seismic hazard methodology, through the use of the most recent ground-motion predictive equations (GMPEs). History ondevelopment of Indonesian seismic hazard map and elaboration on previous researches on seismic hazard analysis until 2008 is presented in Surahman et al., 2008.In 2008, during the First International Conference on Earthquake Engineering and Disaster Mitigation[25] in Jakarta, round-table discussion among Indonesian seismic hazard experts and earthquakeengineers towards the unification of several Indonesianseismic hazard maps developed by different institutionswas originated. Later on, in 2009, a national team(Team-9) was then established for the Revision of SeismicHazard Maps of Indonesia. The probabilistic seismic hazard analysis methodology is adopted for the development of the map. This team successfully developed 2010 Indonesianhazard maps [22] through the development of hazard curves for various earthquake return periods.

The 2010 hazard map was developed adopting the current seismic source zones, seismicity data and recent GMPEs, and PSHA methodology at that time. These 2010 hazard maps provide various earthquake return periods. Also, there are three seismic design maps prepared, for response spectral at $\mathrm{T}=0 \mathrm{~s}$ (PGA), short $(\mathrm{T}=0.2 \mathrm{~s})$, and long $(\mathrm{T}=1 \mathrm{~s})$ periods regarding ASCE-SEI-7-10.

The 2010 hazard map was based on PSHA that hasbeen conducted considering many past large subductionsand shallow crustal earthquakes, such as 2004 Aceh subduction interface $\left(\mathrm{M}_{\mathrm{w}}=9.3\right), 2005$ Nias subduction interface $\left(\mathrm{M}_{\mathrm{w}}=8.7\right), 2006$ shallow crustal Yogyakarta $\left(\mathrm{M}_{\mathrm{w}}=6.3\right), 2006$ Pangandaran subduction interface $\left(\mathrm{M}_{\mathrm{w}}=7.2\right), 2007$ Indramayu subduction intraplate 
$\left(\mathrm{M}_{\mathrm{w}}=7.5\right), 2007$ Bengkulu subduction interface $\left(\mathrm{M}_{\mathrm{w}}=8.4\right)$, 2009 West Sumatra subduction intraplate $\left(M_{\mathrm{w}}=7.6\right), 2009$ West Java subduction interface $\left(\mathrm{M}_{\mathrm{w}}=7.0\right)$. The development of the 2010 hazard map was supported by the Indonesian Ministry of Public Work and National Disaster Management Agency (BNPB) through AustraliaIndonesia Facility for Disaster Reduction (AIFDR).

Further in 2017, New 2017 Indonesian seismic hazard maps [22] have been produced and published. The New 2017 hazard maps are presented in the form of peak ground acceleration (PGA) for 50, 100, 200, 500, 1000, 2500, 5000, and 10,000-year return periods. In addition, spectral response accelerations $(\mathrm{Sa})$ for short period $(0.2$ sec) and a 1 -second period for $2 \% \mathrm{PE}$ in 50 years (equivalent to 2,475 years return period) have been produced. In this case, $84^{\text {th }}$ percentile deterministic seismic hazard analysis (DSHA) as the cap of the PSHA results has also been adopted.

The 2017 seismic hazard maps are updated by considering quality improvement with updating, adding, finding, and identifying new seismic sources of geological, geodetic, seismology \& instrumentation, new GMPEs. New information regarding the identification of active faults with a significant number. The information covers both active faults (251 active faults) that have not been appropriately quantifiedduring the preparation of the 2010 map (previously only 81 faults) that are quantified better based on field research through trenching, carbon dating, epicenter relocation, and strain analysis with geodetic data. Another update was the use of a more complete and more accurate earthquake catalogue by updating theearthquake catalogue until 2016 that relocated with 3D-speed models, and a comprehensive earthquake background source.

The GMPE that also updated for the development of the Indonesian seismic hazard map for 2017, such asfor shallow crustal fault and shallow background sources models has been used the GMPE the latest study that is: Boore-Atkinson NGA West-2 (2013), CampbellBozorgnia NGA West-2 (2013) and Chiou-Youngs NGA West-2 (2013), which is an update from GPME 2008 by its researchers, respectively. In addition, thenew GMPE such as BC Hydro (Abrahamson et al., 2014) was also used for the subduction source model. The above changes which are input parameters for seismic hazard analysis (SHA) have affected the hazard value, especially in areas where there are additional faults. Thisnew hazard map has also been analyzed using two software namely PSHA from USGS and OpenQuake from Global Earthquake Model (GEM), where the hazard maps previously only used USGS software.

\section{Seismic Loading Criteria forBuildings and Infrastructures}

\subsection{Building Structures}

Seismic building codes generally are intended to be applied not only by engineers, but also are used for various purposes by safety inspectors, scientists, developers, contractors, manufacturers, insurance companies, facility managers, and others for various aspects related to seismic risks. Seismic loading design criteria for a high-rise building could be simply referredfrom applicable seismic building codes specifying spectral accelerations at referenced base-rock and corresponding Site-Class to provide design spectra. The seismic building codes in general are designed to provide quality and safety for the building occupants and safeguard their assets and economic investments.

Early stage of Indonesian seismic building codes development was initiated with reference to PPTI-UG (Peraturan Perencanaan Tahan Gempa Indonesia untuk Gedung) - 1983. This code is based on the 1983 Indonesian hazard map, as shown in Fig. 2(a). Response spectra at the ground surface can be selected by taking into account local soil conditions. In PPTI- UG, local site conditions are categorized into two groups, i.e., hard and soft sites.

PPTI-UG 1983 was later renewed in 2002 with the issuance of Procedures for Earthquake Resistance Design in SNI 03-1726-2002. This new regulation was prepared regarding the 1997 Uniform Building Codes (UBC). In SNI-1726-2002, the determination of the design earthquake load was carried out adopting the 2002 Indonesian seismic hazard map, shown in Fig. 2(b). In this SNI, the maximum acceleration value and the acceleration spectra at the ground surface are determined based on the location and local site conditions. In contrast to the previous map, the site conditions in this SNI are grouped into 3 categories, i.e., hard, medium, and soft sites following UBC-1997. These categories are based on the dynamic parameters of the soil to a certain depth which is generally taken asthe top $30 \mathrm{~m}$ below ground surface.

After significant earthquakes hit Indonesia during the year 2000 to 2010, the Indonesia seismic design codehas been updated with SNI-1726-2012 replacing the previous SNI 03-1726-2002 which has been consideredto be out of date. New spectral loading criteria were introduced by providing ground motion values having a $2 \% \mathrm{PE}$ in 50 years (equivalent to 2475 years return period).

The significant issues of this 2012 updated code are not only changing the return period but also accountingfor the uncertainty of the collapse capacity of structures. A method, which determines the risk has been used by implementing direct integral to calculate risk-targeted ground motions (RTGM) of $1 \%$ probability of building collapse in 50 years that is derived by integrating $2 \%$ PEin 50 years hazard curves of the 2010 Indonesian seismic hazard with fragility curve of Indonesian buildings defined to have $10 \%$ probability of collapse. This follows the seismic design criteria developed for the UnitedStates of America by Luco et al. (2007), that has been adopted in ASCE-SEI-7-10. Furthermore, the SNI- 1726-2012 adopted three seismic design maps for Risk-TargetedMaximum Considered Earthquake $\left(\mathrm{MCE}_{\mathrm{R}}\right)$ response spectral short $(\mathrm{T}=0.2 \mathrm{~s})$ and long $(\mathrm{T}=1 \mathrm{~s})$ periods [23], as well as Geometric- Mean Maximum Considered Earthquake $\left(\mathrm{MCE}_{\mathrm{G}}\right)$ ground-motion acceleration as referred from ASCE-SEI-7-10.

Site classification was also updated from the 2002 to 2012 building codes. There is a more specific siteclassification made based on the top $30 \mathrm{~m} \mathrm{N-SPT,} \mathrm{Su}$ 
Undrained shear strength, and shear-wave velocity (Vs) profile from SB (soft rock), SC (hard soil), SD (medium soil), and SE (soft soil). In SNI-2012 building codes SiteClass F (SF) is introduced, in which site-specific response analysis (SSRA) shall be conducted to define the seismic design spectra criteria.
To adjust the mapped short period $\left(\mathrm{S}_{\mathrm{S}}\right)$ and 1-second period $\left(\mathrm{S}_{1}\right)$ spectra and also the $\mathrm{MCE}_{\mathrm{G}}(\mathrm{PGA})$ values for sites other than $\mathrm{SB}$, site coefficients $\mathrm{F}_{\mathrm{a}}, \mathrm{F}_{\mathrm{v}}$, and $\mathrm{F}_{\mathrm{PGA}}$ are applied to $\mathrm{S}_{\mathrm{S}}, \mathrm{S}_{1}$, and PGA, respectively. These site coefficients have been added from the previous 2002 of simply one site coefficient concerning PGA only

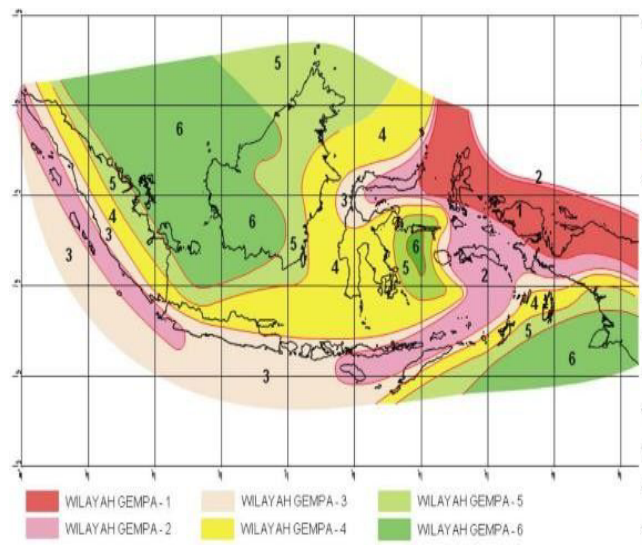

a. Indonesia seismic zone map for building (PPTI-UG 1983)

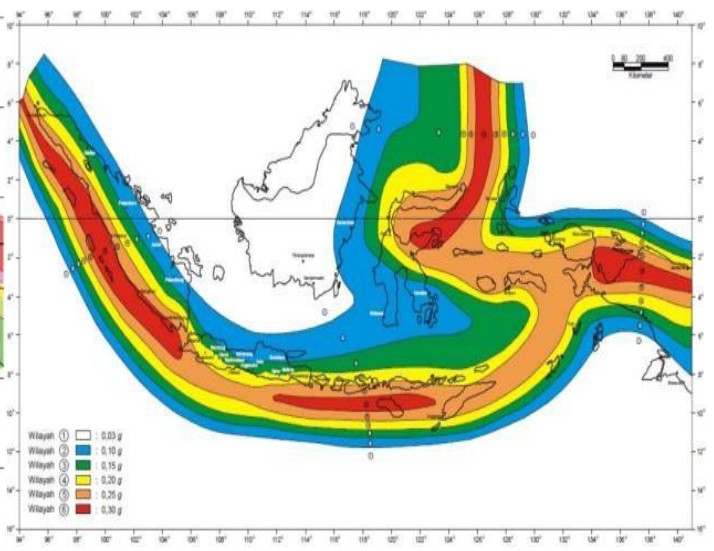

b. Indonesia seismic zone map for building [14]

Fig. 2. Indonesian Seismic Hazard Maps in Previous National Standard

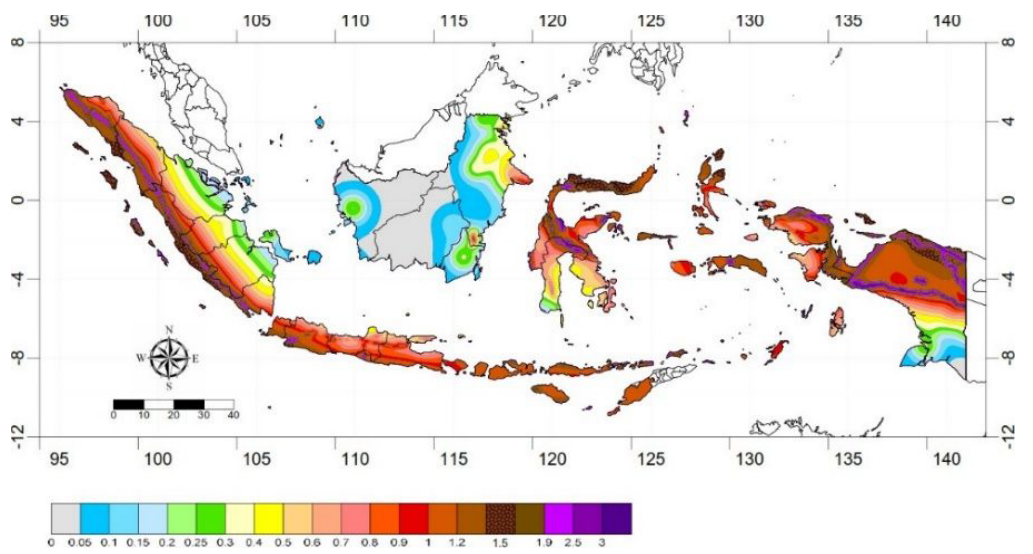

(a)

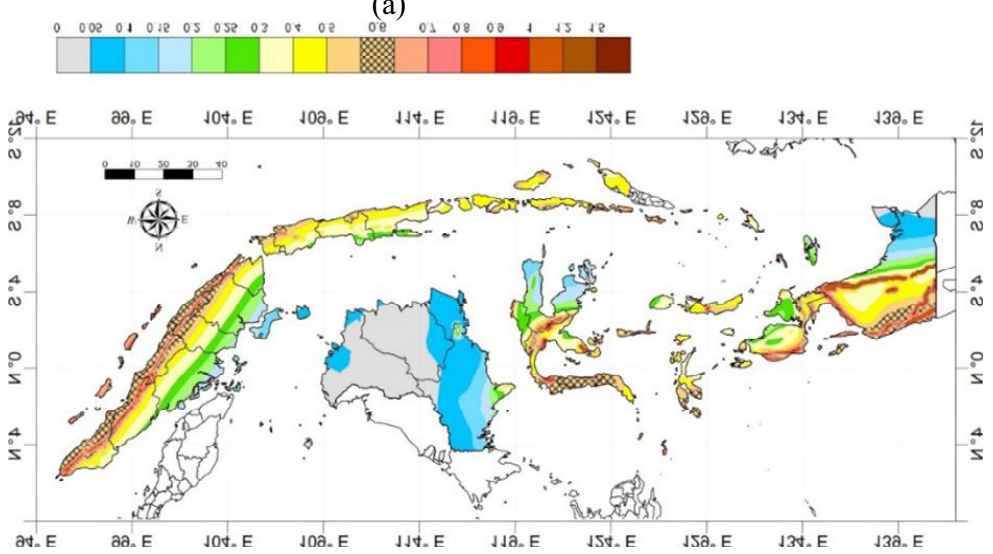

(b)

Fig. 3. (a) Ss Risk-Targeted Maximum Considered Earthquake (MCER) Ground Motion Parameter for $0.2 \mathrm{~s}$ Spectral Response Acceleration (5\% of Critical Damping), Site Class B; (b) S1 Risk-Targeted Maximum Considered Earthquake (MCER) Ground Motion Parameter for Indonesia for $1.0 \mathrm{~s}$ Spectral Response Acceleration (5\% of Critical Damping), Site Class B. [14] 
Further update of the Indonesian seismic buildingcodes 2012 was made in 2019 [14] adopting the update of the Indonesian 2017 seismichazard maps. Figure 3(a) and 3(b) show RTGM maps for Indonesia Building Code SNI1726-2019 at 0.2s and1.0s spectral response acceleration, respectively, Site Class B for 5\% of critical damping [26].

Separately from the updates to the RTGM maps, thesite coefficients used to adjust the mapped values for soil properties have also been updated for the SNI-1726- 2019. In both the SNI-1726-2012 and SNI-1726-2019, the ground motion maps are for an average shear wave velocity at small shear strains in the upper 30 meters of subsurface below a site, $\mathrm{V}_{\mathrm{s} 30}$, of $760 \mathrm{~m} / \mathrm{s}$. To adjust the mapped RTGM ( $\mathrm{S}_{\mathrm{S}}$ and $\mathrm{S}_{1}$ ) and $\mathrm{MCE}_{\mathrm{G}}(\mathrm{PGA})$ values to other site classes, the site coefficients $F_{a}, F_{v}$, and $F_{P G A}$ are applied to $\mathrm{S}_{\mathrm{S}}, \mathrm{S}_{1}$, and $\mathrm{PGA}$, respectively.

The RTGM site coefficients $\left(F_{a}\right.$ and $\left.F_{v}\right)$ have been modified as high as $20 \%$, i.e., $\mathrm{Fv}$ is changed to 1.8 from 1.5 for SD Site Class at $\mathrm{S}_{1}=0.5 \mathrm{~g}$; Fa is changed to 1.2 from 1.0 for SC Site Class at $\mathrm{SS} \geq 1 \mathrm{~g}$, and $\mathrm{Fv}$ is changedto 0.8 from 1.0 for SC Site Class at all values of $\mathrm{S}_{1}$. TheMCE $\mathrm{E}_{\mathrm{G}}$ site coefficient $\left(\mathrm{F}_{\mathrm{PGA}}\right)$ has similarly increased by approximately $20 \%$ for SC Site Class and PGA $\geq 0.4 \mathrm{~g}$, and has increased by approximately $20 \%$ to $56 \%$ for SESite Class at $\mathrm{PGA} \geq 0.25 \mathrm{~g}$. Please note that this modification is also under consideration that the reference subsurface rock is currently specified as $\mathrm{BC}(\mathrm{Vs}=760 \mathrm{~m} / \mathrm{s})$, whereas previously, it is specified as SiteClass B.

Evaluating short-period site coefficient $\mathrm{F}_{\mathrm{a}}$ as shownin Table 1, it is identified that the coefficient of $F_{a}$ in SNI1726-2019 has a slight difference for SE site class at Ss $\geq$ 1.0 than those in ASCE-7-16, for example, $\mathrm{F}_{\mathrm{a}}=1.1$ and 1.2 for SNI-1726-2019 and ASCE-7-16, respectively. However, similar values are shown for the coefficient of $\mathrm{F}_{\mathrm{v}}$ and $\mathrm{F}_{\mathrm{PGA}}$ in SNI-1726-2019 and ASCE-7-16. These new site amplifications are also under consideration concerning Kircher and Associates (2015).

Table 1. Short-Period Site Coefficient, Fa (SNI-1726-2019)

\begin{tabular}{|c|c|c|c|c|c|c|}
\hline \multirow{2}{*}{ Site Class } & \multicolumn{6}{|c|}{$\begin{array}{c}\text { Mapped Risk-Targeted Maximum Considered Earthquake (MCER) } \\
\text { Spectral Response Acceleration Parameter at Short Period }\end{array}$} \\
\cline { 2 - 7 } & $S_{s} \leq 0,25$ & $S_{s}=0,5$ & $S_{s}=0,75$ & $S_{s}=1,0$ & $S_{s}=1,25$ & $S_{s} \geq 1,5$ \\
\hline$S A$ & 0,8 & 0,8 & 0,8 & 0,8 & 0,8 & 0,8 \\
\hline$S B$ & 0,9 & 0,9 & 0,9 & 0,9 & 0,9 & 0,9 \\
\hline$S C$ & 1,3 & 1,3 & 1,2 & 1,2 & 1,2 & 1,2 \\
\hline$S D$ & 1,6 & 1,4 & 1,2 & 1,1 & 1,0 & 1,0 \\
\hline$S E$ & 2,4 & 1,7 & 1,3 & $1,1(1,2)^{*}$ & $0,9(1,2)^{*}$ & $0,8(1,2)^{*}$ \\
\hline
\end{tabular}

Note: *Coefficient in the parentheses ( ) is short-period site coefficient (Fa) of ASCE-7-16

Table 2. 1-Second Period Site Coefficient, Fv [14]

\begin{tabular}{|c|c|c|c|c|c|c|}
\hline \multirow{2}{*}{ Site Class } & \multicolumn{6}{|c|}{$\begin{array}{c}\text { Mapped Risk-Targeted Maximum Considered Earthquake (MCER) } \\
\text { Spectral Response Acceleration Parameter at 1-s Period }\end{array}$} \\
\cline { 2 - 7 } & $S_{1} \leq 0,1$ & $S_{1}=0,2$ & $S_{1}=0,3$ & $S_{1}=0,4$ & $S_{1}=0,5$ & $S_{1} \geq 0,6$ \\
\hline$S A$ & 0,8 & 0,8 & 0,8 & 0,8 & 0,8 & 0,8 \\
\hline$S B$ & 0,8 & 0,8 & 0,8 & 0,8 & 0,8 & 0,8 \\
\hline$S C$ & 1,5 & 1,5 & 1,5 & 1,5 & 1,5 & 1,4 \\
\hline$S D$ & 2,4 & 2,2 & 2,0 & 1,9 & 1,8 & 1,7 \\
\hline$S E$ & 4,2 & 3,3 & 2,8 & 2,4 & 2,2 & 2,0 \\
\hline
\end{tabular}

Furthermore, the parameter $\mathrm{T}_{\mathrm{L}}$ was introduced in SNI1726-2019 to provide more realistic ground motions at periods $\mathrm{T}>4 \mathrm{sec}$ that would affect the design of tall buildings. Long-period transition, $\mathrm{T}_{\mathrm{L}}$, in this case, marks the transition between the constant velocity and constant displacement segments of the Fourier spectrum representing a theoretical fault-rupture displacement history.

Based on several parameters that have been updated such as RTGM, spectral amplification factors, as well as $T_{L}$ parameters, there is a quite significant difference between design response spectrum adopting SNI-1983, SNI-1726-2002, SNI-1726-2012, and SNI-1726-2019 parameters. As an illustration of comparison, the design response spectrum of the city of Banda Aceh is increasing for PGA, short-period ( $0.2 \mathrm{~s})$, 1-second $\left(\mathrm{S}_{1}\right)$, until reaches $\mathrm{T}_{\mathrm{L}}$ parameters $(8 \mathrm{~s})$. An exception is for very long period structures, such as $10 \mathrm{~s}$ to $15 \mathrm{~s}$, the spectral response acceleration tends to decrease. Fig. 4 shows the difference in design response spectrum in the city of BandaAceh, using PPTGIUG (1983), SNI-1726-2002, SNI-17262012, and SNI-1726-2019 spectra parameters.

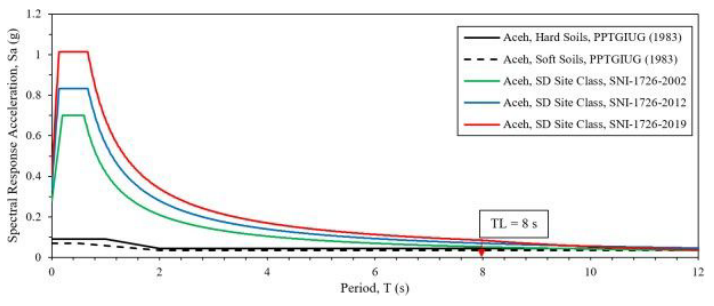

Fig. 4. Design Response Spectrum for Aceh city adoptingSNI-1726-2002, SNI-1726-2012 and SNI-1726-2019 Parameters 
Table 3. Site Coefficient FPGA [14]

\begin{tabular}{|c|c|c|c|c|c|c|}
\hline Site Class & PGA $\leq \mathbf{0 , 1}$ & PGA = 0,2 & $\begin{array}{r}\text { PGA }= \\
\mathbf{0 , 3}\end{array}$ & $\begin{array}{c}\text { PGA }= \\
\mathbf{0 , 4}\end{array}$ & $\begin{array}{c}\text { PGA }= \\
\mathbf{0 , 5}\end{array}$ & PGA $\geq \mathbf{0 , 6}$ \\
\hline$S A$ & 0,8 & 0,8 & 0,8 & 0,8 & 0,8 & 0,8 \\
\hline$S B$ & 0,9 & 0,9 & 0,9 & 0,9 & 0,9 & 0,9 \\
\hline$S C$ & 1,3 & 1,2 & 1,2 & 1,2 & 1,2 & 1,2 \\
\hline$S D$ & 1,6 & 1,4 & 1,3 & 1,2 & 1,1 & 1,1 \\
\hline$S E$ & 2,4 & 1,9 & 1,6 & 1,4 & 1,2 & 1,1 \\
\hline
\end{tabular}

\subsection{Bridge Structures}

Indonesian Government previously developed seismic hazard map and design standard for bridge,namely Standar Perencanaan Ketahanan Gempa untuk Jembatan Jalan Raya [4] in 1992 and Standar Perencanaan Ketahanan Gempa untuk Jembatan[5] in 2008. The seismic zone map for those standards were shown in Fig. 5. Afterward, updatingon seismic design standard was made in 2013 by adopting the AASHTO (2012) design criteria for 1000 years RP (7\% probability of exceedance in 75 years) (Figure 6Fig. 6). This was a significant change, considering the previous national standard set to 500 years RP ( $10 \%$ probability of exceedance in 50 years). Other changes in the 2016 National Standard were site class, site coefficients, and design response spectrum calculation. The seismic hazard map was developedusing the methodology and seismic source parameters established by Team- 9 and had been published in several seminars at Puslitbang Jalan dan Jembatan and the $18^{\text {th }}$ Southeast Asian Geotechnical Conference [1].

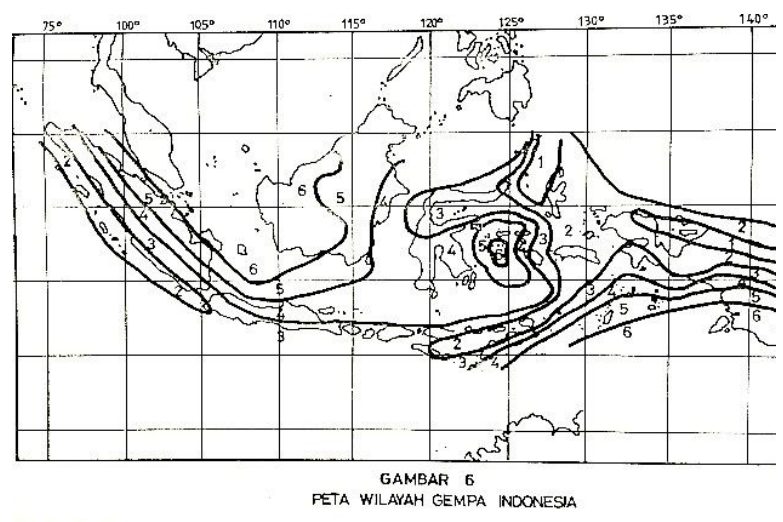

a. Indonesia seismic zone map [4]

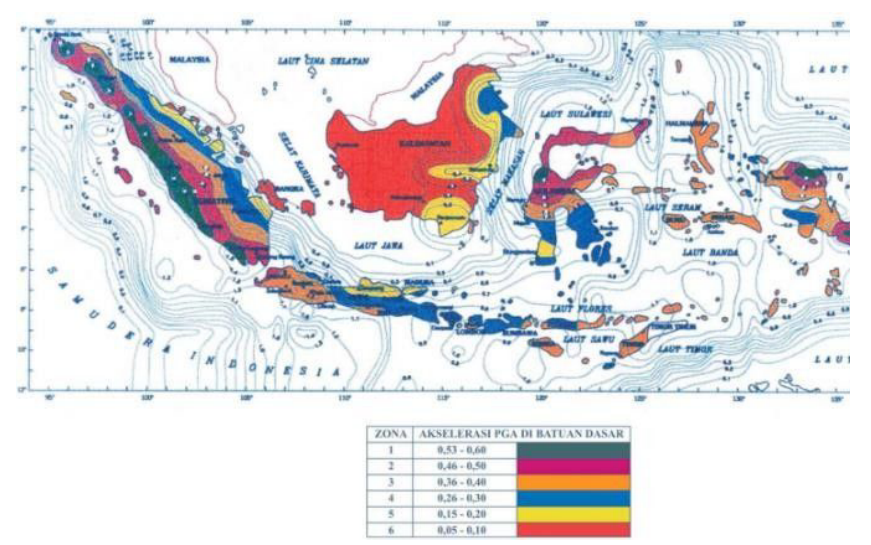

b. Indonesia seismic zone map [5]

Fig. 5. Indonesian Seismic Hazard Maps in Previous National Standard

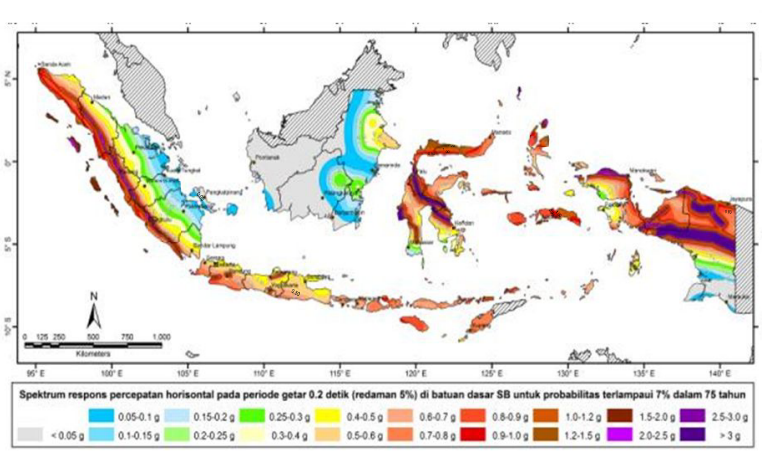

a. Peak Ground Acceleration (PGA) on Rock (SB)

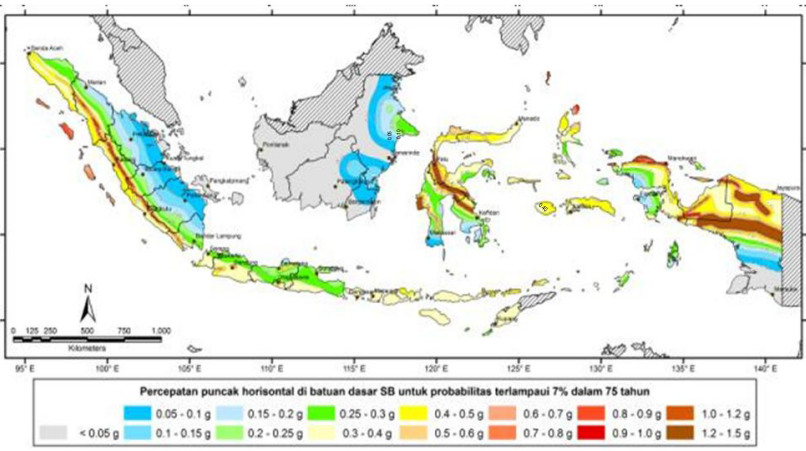

b. Horizontal Spectral Response Acceleration at Period of $0.2 \mathrm{sec}$ on Rock (SB)

Fig. 6. Design Horizontal Peak Ground Acceleration Coefficient (PGA) and Horizontal Response Spectral Acceleration Coefficients Maps in Latest National Standard [6] 
.Design response spectrum for the conventional bridge was generated using 2 procedures i.e., using seismic hazard map and site-specific seismic hazard analysis according to specific location conditions. According to National Standard, site-specific seismic hazard analysisshould be conducted for the near-fault condition or when project location less than $10 \mathrm{~km}$ from active fault and special soil condition or determined as site class F.Design response spectrum derived from seismic hazardmap were based on 3 -point values as seen in Fig. 7. Site amplification factors for each of the periods i.e., PGA0.2 second and 1.0 second are shown in Table 4 and Table 5.

A website version of the seismic hazard map for the conventional bridge to help engineers easily develop the design response spectrum can be seen at http://lini.binamarga.pu.go.id/.

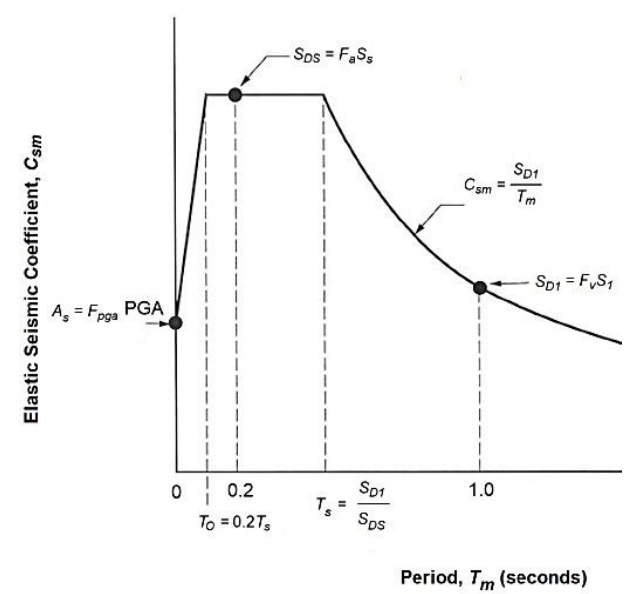

Fig. 7. Design Response Spectrum [6]

Table 4. Site Factors for PGA and Period of $0.2 \mathrm{sec}$

$\left(\text { FPGA and } F_{A}\right)^{[6]}$

\begin{tabular}{|l|c|c|c|c|c|}
\hline \multicolumn{1}{|c|}{ Site Class } & $\begin{array}{r}\text { PGA } \leq \mathbf{0 . 1} \\
\mathbf{S}_{\mathbf{S}} \leq \mathbf{0 . 2 5}\end{array}$ & $\begin{array}{c}\text { PGA }=\mathbf{0 . 2} \\
\mathbf{S}_{\mathbf{S}}=\mathbf{0 . 5}\end{array}$ & $\begin{array}{c}\text { PGA }=\mathbf{0 . 3} \\
\mathbf{S}_{\mathbf{S}}=\mathbf{0 . 7 5}\end{array}$ & $\begin{array}{c}\text { PGA }=\mathbf{0 . 4} \\
\mathbf{S}_{\mathbf{S}}=\mathbf{1 . 0}\end{array}$ & $\begin{array}{r}\text { PGA } \geq \mathbf{0 . 5} \\
\mathbf{S}_{\mathbf{S}} \geq \mathbf{1 . 2 5}\end{array}$ \\
\hline Hard rock (SA) & 0.8 & 0.8 & 0.8 & 0.8 & 0.8 \\
\hline Rock (SB) & 1.0 & 1.0 & 1.0 & 1.0 & 1.0 \\
\hline Firm soil (SC) & 1.2 & 1.2 & 1.1 & 1.0 & 1.0 \\
\hline Stiff soil (SD) & 1.6 & 1.4 & 1.2 & 1.1 & 1.0 \\
\hline Soft soil (SE) & 2.5 & 1.7 & 1.2 & 0.9 & 0.9 \\
\hline Specific soil (SF) & SS & SS & SS & SS & SS \\
\hline
\end{tabular}

Note: Linear interpolation can be used for intermediate values

$\mathrm{S}_{1}=$ horizontal response spectral acceleration on rock (SB) at period of $0.2 \mathrm{sec}$ (Figure $6 \mathrm{~b}$ )

$\mathrm{S}_{\mathrm{S}}=$ locations requiring site-specific geotechnical investigation and dynamic site response analysis

Table 5. Site Factors for Period of $1.0 \sec \left(F_{v}\right)^{[6]}$

\begin{tabular}{|l|c|c|c|c|c|}
\hline \multicolumn{1}{|c|}{ Site Class } & $\mathbf{S}_{\mathbf{1}} \leq \mathbf{0 . 1}$ & $\mathbf{S}_{\mathbf{1}}=\mathbf{0 . 2}$ & $\mathbf{S}_{\mathbf{1}}=\mathbf{0 . 3}$ & $\mathbf{S}_{\mathbf{1}}=\mathbf{0 . 4}$ & $\mathbf{S}_{\mathbf{1}} \geq \mathbf{0 . 5}$ \\
\hline Hard rock (SA) & 0.8 & 0.8 & 0.8 & 0.8 & 0.8 \\
\hline Rock (SB) & 1.0 & 1.0 & 1.0 & 1.0 & 1.0 \\
\hline Firm soil (SC) & 1.7 & 1.6 & 1.5 & 1.4 & 1.3 \\
\hline Stiff soil (SD) & 2.4 & 2.0 & 1.8 & 1.6 & 1.5 \\
\hline Soft soil (SE) & 3.5 & 3.2 & 2.8 & 2.4 & 2.4 \\
\hline Specific soil (SF) & SS & SS & SS & SS & SS \\
\hline
\end{tabular}

Note: Linear interpolation can be used for intermediate values

$\mathrm{S}_{1}=$ horizontal response spectral acceleration on rock (SB) at the period of $1.0 \mathrm{sec}$ (Figure 6c)

$\mathrm{S}_{\mathrm{S}}=$ locations requiring site-specific geotechnical investigation and dynamic site response analysis

\subsection{Dam Structures}

Seismic safety evaluation of dams is part of essential disaster risk assessment, considering the impact could be very catastrophic. International Committee on Seismic Aspects of Dam Design has representatives (dam engineers and earthquake experts) from 26 different countries from Europe, North and South America, Africa, Asia, and Australia, since 1975, following bulletins were published by ICOLD(International Commissions on Large
Dams), which were mainly prepared by the seismic committee. The published bulletins consist among others are of the review of earthquake resistance of dams, the seismic requirement on the design of dams, inspection post-earthquakes and seismic observation, selection of seismic parameters forlarge dams, seismicity of tailings dams, and designfeatures of dams.

Beyond that, the first earthquake hazard maps for dam structure was developed by Najoan (1996). This map was adopted in guidelines for the stability analysis of the 
embankment dam subjected earthquake load as shown in Figure 8 (Pd T-14-2004-A). This standard wasestablished about several international standards, i.e., USCOLD 1985, USBR 1984, USBR1987, and ICOLD 1989. Additionally, this guideline requested analysis with a particular method and specific earthquake level for evaluating the stability of the dam based on the potential risk rating as shown in Tables 6 to 8 .

One (1) year after the establishment of the standard for seismic stability analysis, the Department of Public Works, Research and Development Center of Water Resources issued enhancement of Indonesia seismic zone map for dam structure, adopting Fukushima and Tanaka (1990) ground-motion predictive equation. This map was givenfor the maximum earthquake acceleration values at bedrock (SC) with return periods (RP) of 10, 20, 50, 100, 200, 500, 1000, 5000, and 10,000 years. Based on this developed map, Indonesian zonation is divided intosix (6) i.e., A, B, C, D, E, and F. The distribution was carried out by taking into account the condition of the earthquake magnitude that may occur. The map alsoprovides contour lines of the earthquake coefficients. This earthquake acceleration coefficient was required to be used as the design basis for the stability of the dams. This map was adopted in guidelines for dynamic analysis of embankment dam (Kep. Dirjen SDA 27/KPTS/D/2008,2008).

Seismic requirement for dam safety is stated in two(2) levels of safety. The upper-level earthquake is for ultimate safety termed as Safety Evaluation Earthquake(SEE). The lower level earthquake is for lower event earthquake is used to address serviceability termed as Operating Basis Earthquake (OBE). In this guideline, the earthquake load scenario associated with SEE level ground motions is corresponding to an annual probability of exceedance (PE) of about $1 / 3,000$ to $1 / 10,000$ (depending on risk dam level) is recommendedin defining the SEE probabilistically for high hazard dams. Meanwhile, OBE is defined probabilistically as an event with a reasonable likelihood of occurring during the life of a facility. Thus, it is typically characterized as the earthquake scenario associated with ground motions corresponding to a probability exceedance of about $1 / 100$ to $1 / 200$ (depending on risk dam level).

Nine years after the issuance of seismic analysis guideline for dam structure (2017), Indonesia has published successfully the Indonesian Geotechnical Code (SNI-8460-2017) as well as the new 2017 Indonesian Earthquake Hazard Map. The stability of dam structure due to earthquake also was mentioned in this standard following to reference of ICOLD Bulletin No. 148 (2016). The requirement of the dam safety criteria in this standard for SEE and OBE level earthquakes is shown in Table 9. Furthermore, the peakground acceleration (PGA) map for SEE and OBE earthquakes is corresponding to the 10,000 and 100 year return period also given in the new 2017 Indonesian Earthquake Hazard Map as depicted in Figure 9(a) and 9(b), respectively. Comparison of peak ground acceleration using three standards and maps, i.e., Pd T- 142004-A, Kep. Dirjen SDA 27/KPTS/D/2008 and 2017 Indonesia Seismic Hazard Map in the city of Padang are shown in Table 10

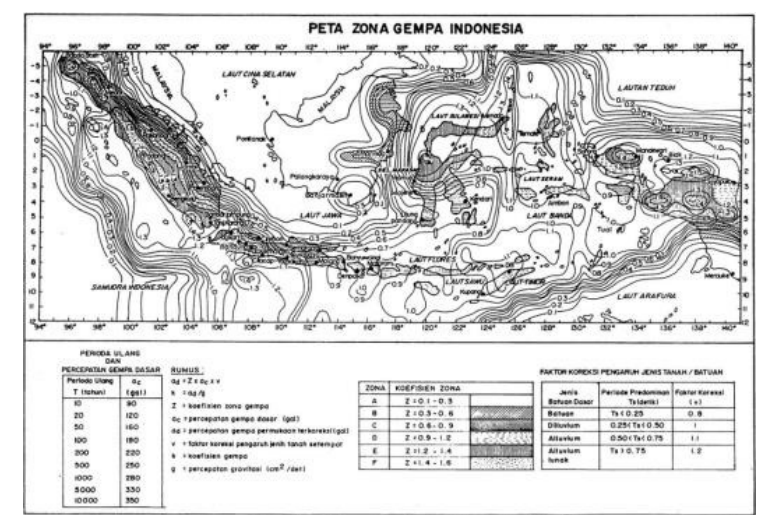

Fig. 8. Indonesia seismic zone map for dam structure (Pd T-142004-A)

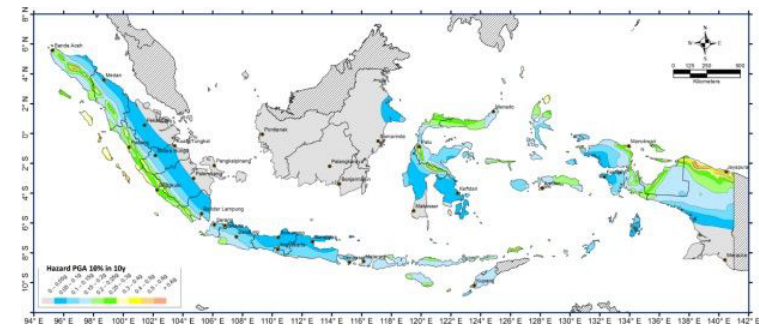

(a)

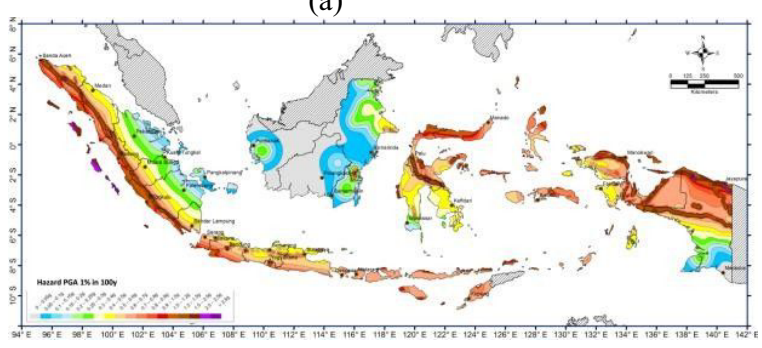

(b)

Fig. 9. Peak Ground Acceleration (PGA) Maps in the 2017 Indonesian Earthquake Hazard Map (a) 10\% probability of being exceeded in 10 years (b) $1 \%$ probability of being exceeded in 100 years

Table 6. Risk Factor Criteria for Dam Safety Evaluation[10]

\begin{tabular}{|r|c|c|c|c|}
\hline Risk Factor & Extreme & High & Moderate & Low \\
\hline \multicolumn{2}{|c|}{ Contribution to risk (weighting points) }
\end{tabular}

\begin{tabular}{|c|c|c|c|c|}
\hline $\begin{array}{c}\text { Capacit } \\
\mathbf{y}_{\mathbf{3}} \\
(\mathbf{h m})\end{array}$ & $\begin{array}{c}>12 \\
0 \\
(6) \\
\end{array}$ & $\begin{array}{c}120-1 \\
(4)\end{array}$ & $\begin{array}{c}1-0.1 \\
(2)\end{array}$ & $\begin{array}{c}< \\
0.1 \\
(0)\end{array}$ \\
\hline Height (m) & $\begin{array}{l}>45 \\
(6)\end{array}$ & $\begin{array}{c}45-30 \\
(4)\end{array}$ & $\begin{array}{c}30- \\
15 \\
(2)\end{array}$ & $\begin{array}{l}<15 \\
(0)\end{array}$ \\
\hline $\begin{array}{c}\text { Evacuation } \\
\text { Requiremen } \\
\text { ts } \\
\text { (No. of } \\
\text { person } \\
\text { s) }\end{array}$ & $\begin{array}{c}>1000 \\
(12)\end{array}$ & $\begin{array}{c}1000- \\
100 \\
(8)\end{array}$ & $\begin{array}{c}100- \\
1 \\
(4)\end{array}$ & $\begin{array}{l}\text { Non } \\
\text { e } \\
(0)\end{array}$ \\
\hline $\begin{array}{l}\text { Potential } \\
\text { Downstrea } \\
\text { m } \\
\text { Damage }\end{array}$ & $\begin{array}{l}\text { Hig } \\
\text { h } \\
(12)\end{array}$ & $\begin{array}{c}\text { Moderat } \\
\mathrm{e}(8)\end{array}$ & $\begin{array}{l}\text { Lo } \\
\mathrm{W} \\
(4)\end{array}$ & $\begin{array}{l}\text { Non } \\
\text { e } \\
(0)\end{array}$ \\
\hline
\end{tabular}


Table 7. The Risk Class of Dam based on the ComputedTotal Risk Factor [10]

\begin{tabular}{|c|c|}
\hline Total Risk Factor & $\begin{array}{c}\text { Risk Class } \\
\text { (Risk Rating) }\end{array}$ \\
\hline $0-6$ & I (Low) \\
\hline $7-18$ & II (Moderate) \\
\hline $19-30$ & III (High) \\
\hline $31-36$ & IV (Extreme) \\
\hline
\end{tabular}

Table 8. Earthquake Load Criteria for Dam Design (Pd T14-2004-A)

\begin{tabular}{|c|c|c|c|c|}
\hline \multirow{2}{*}{$\begin{array}{c}\text { Risk } \\
\text { Class } \\
\text { es } \\
\text { with } \\
\text { Lifeti } \\
\text { me }\end{array}$} & \multicolumn{2}{|c|}{ OBE LeVeI } & \multicolumn{2}{|c|}{ MDE LeveI } \\
\hline & $\underset{\text { (year) }}{\mathbf{T}}$ & $\begin{array}{l}\text { Analy } \\
\text { sis } \\
\text { Meth } \\
\text { od }\end{array}$ & $\begin{array}{c}\text { T } \\
\text { (year } \\
\text { ) }\end{array}$ & $\begin{array}{l}\text { Analys } \\
\text { is } \\
\text { Metho } \\
\text { d }\end{array}$ \\
\hline $\begin{array}{l}\text { IV } \\
\mathrm{N}=50- \\
100\end{array}$ & $\begin{array}{l}100-200 \\
a_{d} \geq 0.1 g\end{array}$ & \multirow{4}{*}{$\begin{array}{l}\text { Earthqu } \\
\text { ake } \\
\text { Coeffic } \\
\text { ient }\end{array}$} & $\begin{array}{c}10,00 \\
0\end{array}$ & \multirow{4}{*}{$\begin{array}{l}\text { Earthqua } \\
\text { ke } \\
\text { Coefficie } \\
\text { ntor } \\
\text { Dynamic } \\
\text { Analysis }\end{array}$} \\
\hline $\begin{array}{l}\quad \text { III } \\
\mathrm{N}=50- \\
100\end{array}$ & $\begin{array}{c}50-100 \\
a_{d} \geq 0.1 \mathrm{~g}\end{array}$ & & 5,000 & \\
\hline \begin{tabular}{l}
\multicolumn{1}{c}{ II } \\
$\mathrm{N}=50-$ \\
100
\end{tabular} & $\begin{array}{c}50-100 \\
a_{d} \geq 0.1 \mathrm{~g}\end{array}$ & & 3,000 & \\
\hline \begin{tabular}{l}
\multicolumn{1}{c}{$\mathrm{I}$} \\
$\mathrm{N}=50-$ \\
100
\end{tabular} & $\begin{array}{c}50-100 \\
a_{d} \geq 0.1 g\end{array}$ & & 1,000 & \\
\hline
\end{tabular}

Table 9. The Dam Safety Criteria based on SNI-84602017

\begin{tabular}{|c|c|c|c|}
\hline $\begin{array}{l}\text { Desig } \\
\text { nLive } \\
\text { (year) }\end{array}$ & $\begin{array}{c}\text { Probability } \\
\text { Exceedance } \\
(\%)\end{array}$ & $\begin{array}{l}\text { Retur } \\
\text { n } \\
\text { Period } \\
\text { (year) }\end{array}$ & Safety Criteria \\
\hline 100 & 1 & $\begin{array}{c}10,000 \\
\text { Safety } \\
\text { Evaluation } \\
\text { Earthquake } \\
\quad \text { (SEE) }\end{array}$ & $\begin{array}{l}\text { - There is no } \\
\text { uncontrolled flow } \\
\text { dwater } \\
\text { - Maximum } \\
\text { vertical } \\
\text { deformation of } \\
0.5 \text { freeboard } \\
\text { - Maximum } \\
\text { horizontal } \\
\text { deformation of } \\
0.5 \text { thickness of } \\
\text { the filter }\end{array}$ \\
\hline 100 & 50 & $\begin{array}{c}145 \\
\text { Operating } \\
\text { Basis } \\
\text { Earthquake } \\
\quad(\mathrm{OBE})\end{array}$ & $\begin{array}{c}\text { - Minor } \\
\text { damageafter } \\
\text { the } \\
\text { occurrence of } \\
\text { an earthquake } \\
\text { - No damage or } \\
\text { loss of service } \\
\text { must happen }\end{array}$ \\
\hline
\end{tabular}

Table 10. Comparison of PeakGround Acceleration at OBEand MDE Level in Padang City

\begin{tabular}{|l|c|c|c|}
\hline \multirow{2}{*}{$\begin{array}{c}\text { Earthquake } \\
\text { Level }\end{array}$} & $\begin{array}{c}\text { Peak Ground Acceleration (g) } \\
\text { Pd T-14- } \\
\mathbf{2 0 0 4 - A ^ { ( 1 ) }}\end{array}$ & $\begin{array}{c}\text { Kep. Dirjen } \\
\text { SDA 27 / } \\
\text { KPTS / D / } \\
\mathbf{2 0 0 8}\end{array}$ & $\begin{array}{c}\text { 2017 Indonesia } \\
\text { Seismic Hazard } \\
\text { Map }^{(\mathbf{2})}\end{array}$ \\
\hline $\begin{array}{c}\text { OBE (100-year } \\
\text { return period) }\end{array}$ & 0.29 & 0.32 & 0.34 \\
\hline $\begin{array}{c}\text { MDE (10000- } \\
\text { year return } \\
\text { period) }\end{array}$ & 0.54 & 0.55 & 0.94 \\
Note: ${ }^{(1)} \begin{array}{c}\text { Peak ground acceleration are derived } \\
\text { aboutAlluvium Soils }\end{array}$ \\
$\begin{array}{l}\text { (2) Peak ground acceleration are derived about } \\
\text { SD SiteClass }\end{array}$
\end{tabular}

\section{Vulnerability, Associated Risk, and its Reduction Efforts}

Challenges and demands to develop an optimum construction quality of buildings and infrastructures arein the aspects of their safety and cost-effectiveness. These two aspects always need to be considered for future new constructions.

Buildings and infrastructures development in Indonesia keeps increasing in line with the economic development through a national budget plan. The development of many cities are growing relatively fast in the last decades. In addition to the existing vulnerabilities under past constructions processes and past building codes, there is a potential for vulnerabilityand seismic risk accumulation during the physical and social development of the cities and communities. The vulnerability of the new constructions could be associated with various aspects that are not well implemented well within the risk chain. With these potential accumulated vulnerabilities, then there is the potential of seismic disaster risks under the current conditions. These risks may be passed to generations ahead unless systematic disaster risk-reduction management plans are implemented.

General evaluation of the current conditions would suggest that the current buildings and infrastructures in Indonesia are vulnerable to various degrees as represented by the current and past construction systemto date. Many building and infrastructure damages through post-disaster surveys from several large earthquakes in Indonesia for the last 25 years have indicated vulnerabilities of many types of buildings and bridges. These vulnerabilities are considered to be among others due to a lack of knowledge on earthquakeresistance design and constructions practice as well as alack of building enforcement by the local authorities.

\subsection{Buildings Vulnerability}

Several post-earthquake disaster surveys had been conducted. The surveys showed that the collapsed buildings were mostly non-engineered buildings consisting of one or two-story houses, shops, religious and poor structural quality school buildings. Most of the collapsed residential buildings were also non-engineered masonry houses. They were one story tall with 
unreinforced clay, brick, or block masonry in cement or lime mortar and no particular connectionframe between the timber roof and the walls. Based on the surveys and evaluations in the field, many building structures did not meet earthquake resistance requirements. In addition to the building structures, other contributing factors to the building damages werethe subsurface conditions, type of foundation and its dimensions, local topographical conditions, and the intensifying of the earthquake.

An example of a post-earthquake survey was carriedout through the post-disaster of the 30 September 2009 Padang earthquake [21]. A total of 3,896buildings were surveyed in the Padang and Pariaman region. This comprised a range of types which included medical facilities (108), educational buildings (460), commercial buildings (479), and residential structures $(2,268)$. The survey works also entailed 1,700 interviews with residents. Buildings of all age categorieswere damaged and nominally engineered structures alsosuffered significant damage. Unreinforced masonry, that was not part of the structural system, was required to provide the needed resistance to seismic actions. Observations revealed poor structural configurations, poor detailing of reinforcement, and the use of low-quality construction materials. Analysis of the surveyed buildings consists of different types of structures on physical damage associated with the cost of repair (damage index) using quantity surveying information. Fig. 10 shows nine- benchmark damage models resulting from the survey and analysis. Further detail of the surveyed buildings analysis can be referred to in Sengara et al. (2010).

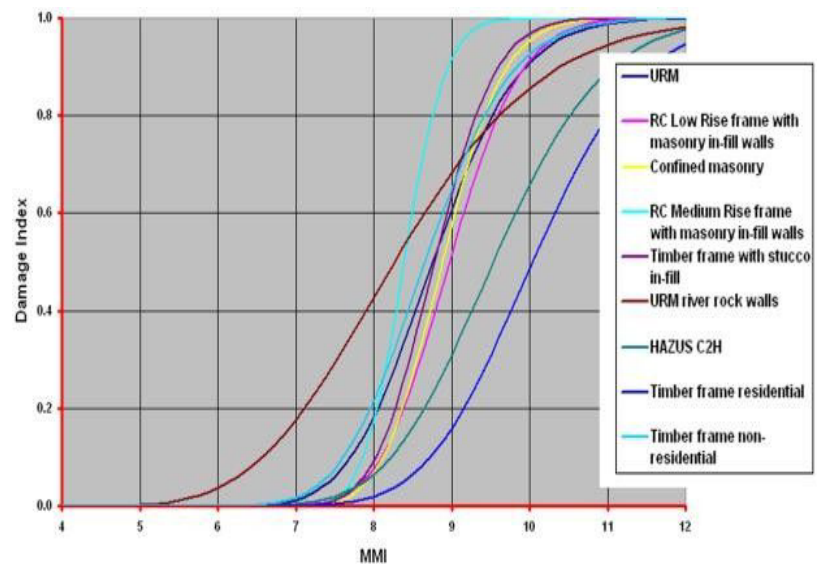

Fig. 10. Benchmark vulnerability models derived from Padang Earthquake damage observations [21].

The case of the post-Padang survey has identified that confined masonry construction in particular sufferedlower damage levels than the unreinforced masonryequivalent. The promotion of cost-effective construction practices which reduce vulnerability and the development of other structural systems with these attributes are central to reducing earthquake risk. Promotion on, enforcement of seismic building codes, training on, and community-based earthquake resistance constructions for buildings are vital to vulnerability and disaster risk reductions. The ninebenchmark models could be used as general measures of vulnerabilities of many buildings with similar types in Indonesia and identify its potential damage and its associated risks. A damage index of as high as 10 to more than $50 \%$ is anticipated for most building types for MMI8 to 9 . This nine-benchmark model could be adopted for the preliminary risk-assessment process subjected to future potential earthquakes as supporting input in the formulation of disaster risk reduction management plans for cities in Indonesia.

\subsection{Bridge Vulnerability}

Although the performance of a bridge is based on the interaction of all its components, certain bridge components are more vulnerable to damage than othersi.e., connection, bearings, piers, columns, foundations, and abutment. Of these, connections, bearings, and inadequate seat length are the most common reasons forbridge failure and the least costly to fix. Since evaluation on bridge vulnerability post-earthquake inspection of bridges in Indonesia has not been conducted comprehensively, empirical fragility curves for the conventional bridge could be estimated using FEMA224 (1991). Damage curves for the conventional bridgesare based on ATC-13 data for FC 24, multiple simple spans, and FC 25 continuous/monolithic bridges (includes single-span bridges).

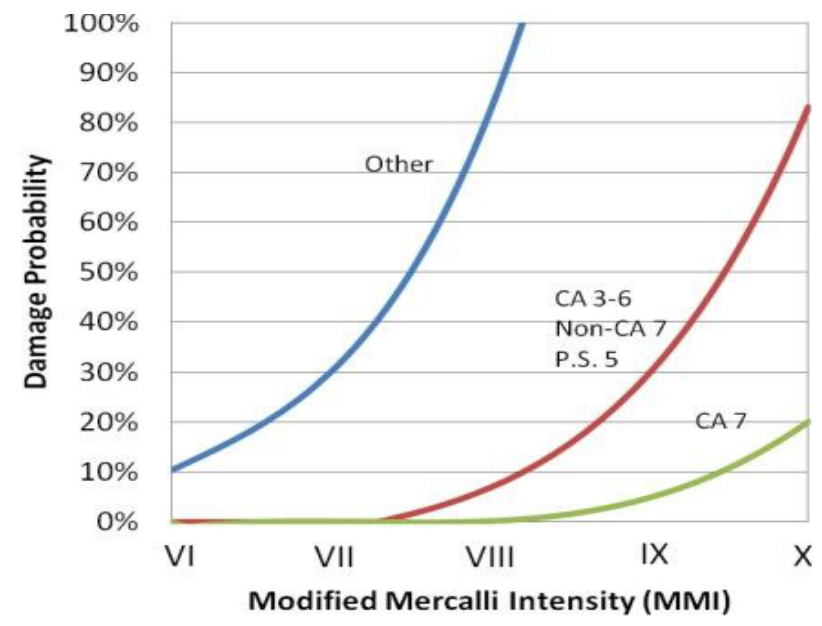

Fig. 11. Judgemental damage curves for conventional bridges[9]

Due to changes in the seismic design criteria and the design concepts it may be necessary to perform several seismic safety checks during the long economical life of existing bridges. It must be pointed out that both new and existing bridges must satisfy today's safety criteria. Therefore, a risk-based approach in which the remaining service life and the acceptable investment cost should be considered. It is essential to develop a vulnerability bridge model for Indonesia.

\subsection{Associated Risks and Reduction Efforts}

It has been identified and elaborated previously throughthe post-disaster survey as well as through identificationon the future potential hazards that many existing buildings and infrastructures in Indonesia is consideredto have various levels of vulnerability and associated disaster risks. The risks are accumulated through past constructions with evolving hazard maps and building codes. Additional risks 
would also be contributed by the performance of other components implemented within the risk-chain, previously noted.

The necessity of disaster reduction for sustainable development and social stability was recognized since several great earthquakes repeatedly occurred in Indonesia. Over the last 10 years, many research institutions, universities, including association professions in Indonesia have significantly increased their efforts towards understanding earthquake hazards and their mitigation on the impact of future large earthquakes. Some of the recent efforts to mitigate the impacts of earthquake hazards have been described briefly in this paper. The actions include updating of the seismic hazard maps of Indonesia 2010 and 2017, revision and continuous updating of building and infrastructure design codes, and development of design codes associated with geotechnical structures (SNI-8460-2017). Development of seismic micro-zonation maps for citiesin Indonesia as supporting reference on-site-classification for residential housings and other low-story buildings would be considered necessary.

In 2012, the Ministry of Public Works has practically implemented SNI 1726-2012 to replace SNI 03-17262002 as a national code for earthquake resistance building design. The new code for buildings follows theconcept of Maximum Considered Earthquake Geometric Mean $\left(\mathrm{MCE}_{\mathrm{G}}\right)$ and Risk-Adjusted Maximum Considered Earthquake $\left(\mathrm{MCE}_{\mathrm{R}}\right)$ adopted in ASCE 7-10.This has been a significant effort towards enhancement in the development of Indonesian seismic building codes from a hazard-based approach to a new concept of a uniform riskbased approach. Five years later after launching the 2012 code, the new seismic hazard maps have been enhanced (2017), and soon afterward the new maps were adopted in the SNI 1726-2019.

Updating of national standards for the design of infrastructure is also conducted for bridges, dams, and other structures. Type of infrastructure code will utilize hazard maps having different return periods. Indonesia has published successfully the Indonesian GeotechnicalCode (SNI-8460-2017) that somehow in general accommodates seismic requirements for many infrastructures. Furthermore, the new 2017 Indonesian seismic hazard maps have included several return periods that facilitate the design of many infrastructures.

Concern on the vulnerability of the existing bridge has been realized by the Directorate General of Highway. Currently, the directorate inspected a conventionalbridge located at National Road in Indonesia to evaluateeach of its conditions and prepare for maintenance and rehabilitation programs. Information of each of the bridge's conditions was stored at a web database namely, http://inspeksijembatan. pusjatan.pu.go.id. After a large earthquake, a specific survey was also conducted to identify the influence of seismic activity on the existing bridges nearby the epicenter. Mitigation scheme to retrofit existing bridges evaluated according to the damages due to large post-earthquake events. Typical damages were shown below (Fig. 12 -16).

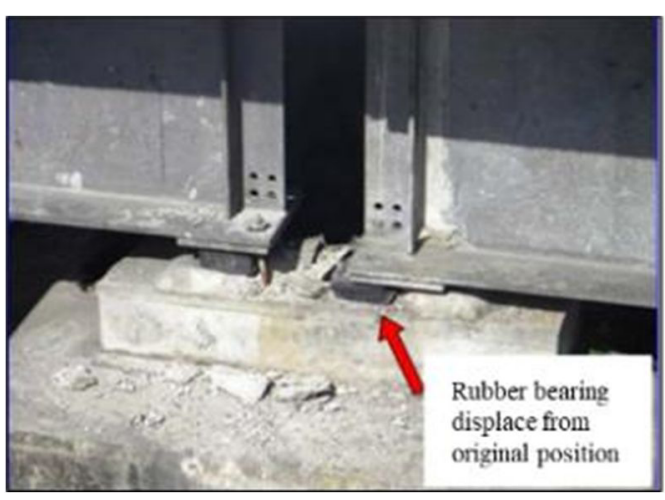

Fig. 12. Damages of bridge deck due to the displacement of rubberbearing post-Padang Earthquake in 2009 [27]
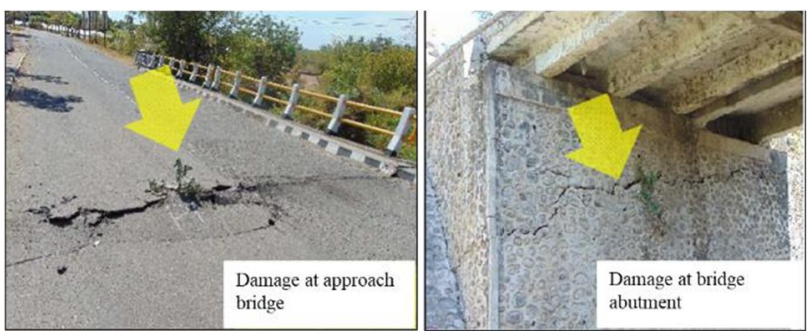

Fig. 13. Damages of bridge deck due to compression effect in longitudinal direction post-Nusa Tenggara Barat Earthquake in 2018 [27]

Institute of Road Engineering and PT. Wiratman Chodai Indonesia is currently developing a technical guideline for inspection, evaluation, andcountermeasures of bridge structure against seismic risk. In this guideline 3 (three) concept, seismic retrofitting methods were introduced i.e., bridge element reinforcements, whole bridge reinforcements, and preventive measures against falling bridges as illustratedin Figure 14 to Figure 16.

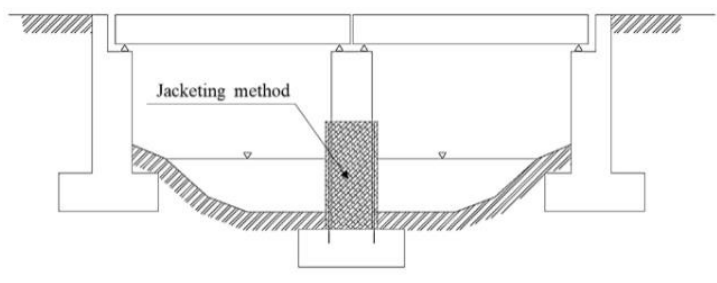

Fig. 14. Example of bridge element reinforcement (Toshiro. Y, 2019)

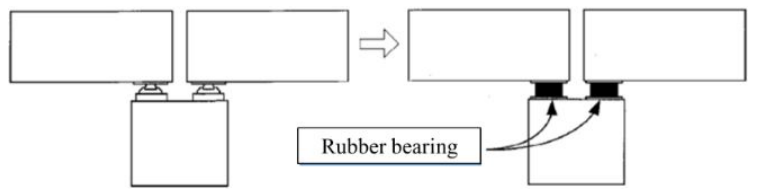

Fig. 15. Example of whole bridge reinforcement using seismic isolation (Toshiro. Y, 2019)
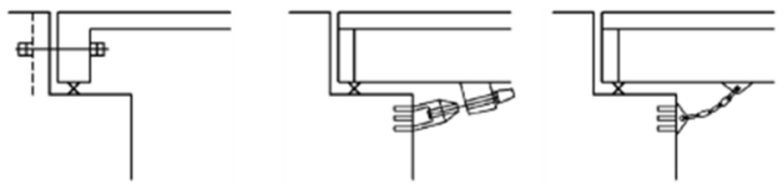

Fig. 16. Example of preventive measures against falling bridge using restrainer (Toshiro. Y, 2019) 


\section{Concluding Remarks}

Seismic building and infrastructure (bridge and dam) spectral design load for Indonesia has evolved over the last three decades. During the development of seismic hazard mapping through the improvement of seismic source zoning and its corresponding seismic parameters, as well as the lower probability of exceedance requirement, there is a tendency that the spectral designloads requirements for buildings, bridges, dams, and other infrastructures to increase in most areas of Indonesia. Recent spectral design load requirements forbuildings and infrastructures for new construction in Indonesia are in general directed toward inline with many International Building Codes. An increase in spectral design loads requirements would tend to expose many existing buildings and infrastructures to be at a higher level of vulnerabilities and risks.

Many building and infrastructure damages postdisaster surveys from several large earthquakes in Indonesia have indicated vulnerabilities of many types of buildings and bridges. Vulnerability building-damage models have been developed Post-Padang 2009 earthquake. The models could be adopted as preliminary bases for the risk assessment process for many types of buildings. High to very high risks of building damages need to be anticipated for many existing buildings and infrastructures under the current spectral design load in many high seismic potential areas.

It is essential to prevent or minimize building and infrastructure collapses or damages from future earthquakes through:

- Provision of proper engineering design parameters.

- Improvement of building codes and guidelines.

- Proper design, good quality construction, and building and infrastructure design enforcements.

- Systematic and good construction supervision.

- Continuous updates of seismic hazard maps and enhancement of building and infrastructures codes areexpected.

- Disaster risk assessment of buildings and infrastructures demands continuous enhancement of building vulnerability models and development of vulnerability models for infrastructures such as bridges.

Assistance by Mr. Ahmad Sulaiman for hiscontribution in editing this paper is highly appreciated. The authors are thankful to team members in the development of Indonesian seismic hazard maps and thecorresponding SNI for providing all the data andinformation in this paper. Other colleagues who have participated in the contribution in the supportingmaterials referred to in this paper are also appreciated.

\section{References}

1. F. Aldiamar, M. Irsyam, I W Sengara, M. Asrurifak, Proposed seismic hazard map for conventional bridge code in Indonesia, $18^{\text {th }}$ Southeast Asian Geotechnical Conference, Singapore (2013)

2. American Association of State Highway and Transportation Officials (AASHTO), Guide
Specifications for LRFD Seismic Bridge Design, 2nd Edition, Washington (2012)

3. ASCE 7-10, Minimum design loads for buildings and other structures, American Society of Civil Engineers, 1 edition, ISBN-10:0784410852 (2010)

4. National Standardization Agency, SNI 03- 2833 Earthquake Resistance Planning Procedures for Highway Bridges, BSN, Jakarta (1992)

5. National Standardization Agency, SNI 2833:2008 Earthquake Resistance Planning for Bridges, Indonesian National Standard, Jakarta (2008)

6. National Standardization Agency, SNI 2833:2016 Bridge Design Against Earthquake Load, Indonesian National Standard, Jakarta (2016)

7. B. C. H. Ferner.. Indonesian Earthquake Study. New Zealand Bilateral Assistance Programme to Indonesia, 1-7 (1979)

8. Department of Public Works, Directorate General of Human Settlements, Directorate of Building Problems. Indonesian Earthquake Resistant Planning Regulations for Buildings (1983)

9. Federal Emergency Management Agency (FEMA), Seismic Vulnerability and Impact of Disruption of Lifelines in the Conterminous United States. Applied Technology Council, California (1991)

10. ICOLD.. Selection Seismic Parameters for Large Dams - Guidelines. Bulletin, 72 (1989)

11. ICOLD. Selection Seismic Parameters for Large Dams - Guidelines. Bulletin, 148 (2016)

12. Indonesian Standard Code, SNI 03-1726-2002, Earthquake Resistance Design for Buildings, National Standardization Agency (2002)

13. Indonesian Standard Code, SNI 1726-2012, Earthquake Resistance Design for Buildings, National Standardization Agency, 2012.

14. Indonesian Standard Code, SNI 1726-2019, Earthquake Resistance Design for Buildings, National Standardization Agency (2019)

15. M. Irsyam, I.W. Sengara, F. Aldiamar, S. Widiyantoro, W. Triyoso, D.H Natawijaya, E. Kertapati, I. Meilano, M. Asrurifak, M. Ridwan, Suhardjono, Development of Seismic Hazards Map of Indonesia for Revision of SNI 03-1726- 2002, A Report submitted to Australia Indonesia Facility for Disaster Reduction (AIFDR) and National Agency for Disaster Management, Institute for Research and Community Services, Institut Teknologi Bandung, (2010)

16. Irsyam et al., National Center for Earthquake Studies (PuSGeN): Map of Indonesia Earthquake Sources and Hazards in 2017, ISBN: 978-602- 5489-01-3, (2017)

17. E. Kertapati, Probabilistic Estimates of the Seismic Ground Motion Hazard in Indonesia. Proceeding on National Conference on Earthquake Engineering, Indonesian Earthquake Engineering Association, Bandung (1999) 
18. Luco, Nicolas, Ellingwood, B.R., Hamburger, R.O., Hooper, J.D. Kimball, J.K, Kircher, C.A, RiskTargeted versus current seismic design maps for the conterminous United States, 163-175, in Structural Engineers Association of California 2007 Convention Proceedings, Callifornia (2007)

19. T.F. Najoan, S. Djanasoedirdja, S. Ruhijat, Map of the Earthquake Zone as a result of the Review and How to Use it as a Proposal in the Design of Earthquake Resistant Irrigation Buildings. Journal of the Research and Development Center for Irrigation, 36, 22-36 (1996)

20. T.F. Najoan, A. Suharjoyo, A. Buditomo, S. Wibowo, Rizaldi, R.B. Nasution, Indonesia Earthquake Zone Map for Determination of Maximum Earthquake Acceleration on the Surface. Proceedings of the National Conference on Seismic Engineering, Bandung (1999)

21. I.W Sengara, M. Suarjana, D. Betham; N. Corby; M. Edwards, M. Griffith; M. Wehner; R. Weller, The 30th September 2009 West Sumatra Earthquake, Padang Region Damage Survey, GeoScience Australia (2010)

22. I.W. Sengara, M. Irsyam, I.D. Sidi, W. Merati, K.S. Pribadi, M. Suarjana, M. Edwards, Some Recent Efforts in Earthquake Hazard and Risk Analyses for Disaster Risk Reduction in Indonesia, in the 2nd International Conference on Earthquake Engineering and Disaster Mitigation (ICEEDM). Surabaya, Indonesia (2011)

23. I.W. Sengara, M. Irsyam, G.W. Merati, I.D Sidi, M. Suarjana, A. Mulia, M.A. Yulman, D. Hutabarat,
Development MCER (Risk-Targeted Maximum Considered Earthquake) through Investigation of Hazard and Fragility Curve, Research Report IMHERE Project B.2C FTSL, Institut Teknologi Bandung (2012)

24. I.W. Sengara, I. Masyhur, I.D. Sidi, A. Mulia, M. Asrurifak, D. Hutabarat, 2015. Development of Earthquake Risk-Targeted Ground Motion for Indonesian Earthquake Resistance Building Code SNI 1726-2012, in 12th International Conference on Application of Statistic and Probability in Civil Engineering (ICASP), July 12-15, Vancouver, Canada (2015)

25. I.W. Sengara, M.A Yulman, P. Sumiartha, A. Mulia, Development on Risk-Based Seismic Design Criteria and Ground Motions for High-Rise Buildings in Jakarta, in the 3rd International Conference on Earthquake Engineering and Disaster Mitigation (ICEEDM). Bali, Indonesia (2016)

26. I.W. Sengara, M. Irsyam, I.D. Sidi, A. Mulia, M. Asrurifak, D. Hutabarat, W. Partono, New 2019 RiskTargeted Ground Motions for Spectral Design Criteria in Indonesian Seismic Building Code, in the 4th International Conference on Earthquake Engineering and Disaster Mitigation (ICEEDM). Padang, Indonesia (2019)

27. W. A. Riyono, Focus Group Discussion Draft Pedoman Pemeriksaan, Evaluasi dan Perkuatan Struktur Jembatan Terhadap Risiko Gempa Bumi, Presentation Materials, Institute of Road Engineering, Bandung (2019). 